UDC 339.56:656

JEL Classification: F19, L81, M31, M39

Iryna Ivanova

PhD in Pedagogy, Associate Professor Associate Professor of Economics, Entrepreneurship and Marketing Department

Tatiana Borovyk

Senior Lecturer of Economics, Entrepreneurship and Marketing Department

Alona Rudenko

Lecturer of Economics, Entrepreneurship and Marketing Department

Tamila Zalozna

Lecturer of Economics, Entrepreneurship and Marketing Department

Cherkasy StateBusiness College

(Cherkasy, Ukraine)

\title{
BLACK FRIDAY AS A TOOL FOR SALES PROMOTION
}

The article summarizes scientific views and defines the term of sales promotion. Features of promotion and sales promotion in B2C (Business-to-Consumer) markets are revealed. The use of digital marketing tools in the process of stimulating the sales of goods through digital channels, in particular through online stores, as well as the use of search engine optimization (SEO) and SMM-marketing is substantiated. Marketing communications and sales promotion elements used by retailers when preparing for seasonal sales are considered. The activity of consumers to retailers in the period of the preparation for grand sales, tools used by retail trade to influence the consumer and improve the activity of sales of goods is studied. The authors summarize and analyze statistic data of such online platforms as Black-friday.global, Picodi, Google Trends. The factors influencing the opportunities of online shopping and retail during Black Friday are explored and outlined. The peculiarities of trading platforms functioning, which provide online shopping space for various retail enterprises and offer marketing communications of retailers to increase the efficiency of product promotion on the Internet, are highlighted.

Keywords: product promotion, sales promotion, Black Friday, marketing communications, digital marketing, retail, marketplace.

\section{DOI: 10.15276/mdt.4.4.2020.3}

Statement of the problem in general form and it's connection with important scientific or practical tasks. The use of modern digital technologies in marketing simplifies the system of promoting goods and services on the Internet, as well as provides significant benefits to the consumer, who has the opportunity to buy anything in any part of the world without leaving home. Powerful development of the IT sphere and digital marketing forms new channels of communication, which erase geographical boundaries in expanding such market relations as $\mathrm{B} 2 \mathrm{C}$ (Business-to-Consumer). The transition of retail trade to an electronic business model establishes cross-border cooperation in the field of product promotion, provides an opportunity to exchange information and join the established traditions of marketing activities.

(C) 2020 The Authors. This is an open access article under the CC BY license (http://creativecommons.org/licenses/by/4.0) 
According to the research conducted by Black Friday Global [1], the global trend is to arrange pre-holiday sales before Thanksgiving Day. Fashion retail expert A. Boyko calls this event a marketing move, because "the middle of the season, when consumer interest falls is the perfect time to improve cash flow through sales" [2]. One of such big sales is Black Friday, which washes away borders and traditions covers the whole world like a fever. Retailers use all available marketing communications to promote the sale of goods on Black Friday. The most pressing issue for commercial enterprises around the world is the need to intensify sales through marketing activities. The source of investigating methods to increase sales in retail is the collection and analysis of statistical, analytical information, judgments of independent expert analysts, the results of the analysis of companies and their conclusions, which are the basis for further research. According to experts in the field of marketing communications, it is necessary to single out and explore in more detail Black Friday seasonal sale, as one of the areas of sales promotion.

Analysis of the latest research and publications, which init iated the solution of this problem and on which the author relies. Researches by such foreign scientists as R. Mallin, W. Pride, D. Jobber and Ph. Kotler touch upon the issue of sales promotion [7]. A significant amount of publications by domestic scientists is devoted to the sales policy of the enterprise and product promotion, in particular, the peculiarities of sales promotion are studied by N.V. Romanchenko, A.I. Kovranska, Y.M. Karpenko [8], O.V. Sheremetinskaya [9]; marketing communications as a process of product promotion are considered by T.O. Prymak, I.V. Korol, S.Y. Khaminich, A.E. Kalnitsky, Ya.F. Kopusyak [10]; ways to promote goods to customers in reatiling are analysed by O. Yusupova, V. Yarnykh, L.O. Chorna. etc. But the issue of sales promotion during the seasonal sales of Black Friday is insufficiently investigated and scientifically substantiated among domestic marketing scientists and is a topical research.

Highlighting the previously unresolved parts of the general problem to which the article is devoted. The purpose of the research is to study the process of promoting goods through the retail network using digital marketing tools used during seasonal sales; substantiate consumer behaviour, growth of their interest in sales on Black Friday; analyse sales dynamics in Ukraine and the world, as well as identify the most popular marketplaces.

Formulation of the purpose of the article (statement of the problem). To achieve the set goal, the following scientific objectives are outlined: to consider marketing features in such markets as B2C; generalize digital marketing tools used by online stores to promote goods through the global network; explore marketing activities that boost sales (for example, Black Friday seasonal sale); find out the conditions of promotion of Internet retailers goods through electronic trading platforms and price units (marketplaces).

Statement of the main material of the research with full justification of the scientific results obtained. Marketing uses the term "Business-to-Consumer" B2C more and more frequently, which means the process of interaction between the company and the end consumer, i.e. the sale of goods, services or information [3]. This type of relationship aims to make direct sales with minimal involvement of intermediaries. Marketing features in B2C markets are as follows [4]:

- manufacturer is intended to interact with end users;

- the decision to purchase goods is made independently;

- the consumer is not an expert and when buying goods is guided not only by their needs but also emotions;

- short sales cycle;

- a single buyer is not important for the business, but only sales volumes are;

- use of mass communications is a must. 
Characteristic of the market type "Business-to-Consumer" is the promotion of goods on the Internet, which contributes to "strengthening global integration processes, expanding international exchange of goods, services and capital, spreading joint ventures" [5, p. 294]. Every year new methods of product promotion and sales promotion appear in the field of marketing. It is advisable to consider digital marketing tools that accelerate consumer awareness of products and are one of the easiest channels for their promotion. According to D.V. Yatsyuk, "digital media provide rapid dissemination of news and information and become the main means of advertising and interaction with the client" $[6, p$. 70]. Choosing the promotion of goods through digital channels, including the creation of an online store, search engine optimization (SEO), social media marketing (SMM-marketing), the seller focuses on the customer who uses devices with Internet access, i.e computer, tablet, smartphone, etc.

The most pressing issue for companies around the world is the need to increase sales through marketing activities. Over time, the consumer becomes more demanding of the seller and small 10-15\% discounts do not give entrepreneurs the desired result. Ph. Kotler considers sales promotion as "the use of multifaceted means of incentive action, which aim to accelerate and / or strengthen the market reaction" [7]. Y.M. Karpenko, referring to competent sources, notes that the category of "stimulating the sale of goods" is defined as a set of techniques that are applied throughout the life cycle of goods to consumers, traders and its own sales staff to maximize the number of new buyers" [8, p. 336]. O.V. Sheremetynska considers sales promotion as "the use of short-term measures designed to respond quickly to the market in response to the company's supply of its products" [9, p. 336]. A.E. Kalnytsky and Y.F. Kopusyak divide all sales promotion tools into three groups:

- general incentives (at the point of sale) that are characterized by the given theme and are a tool for the general revival of trade (anniversaries, opening ceremonies);

- selective incentives that involve the placement of goods outside the general placement in a favorable position (at the beginning of the series); the goods can be concentrated also in the other place of a trading hall;

- individual incentives are carried out in the places of general expedition of goods and, as a rule, are initiated by the manufacturer (advertising poster, etc.) [10, p. 95].

With every passing year new methods of sales promotion are appearing in marketing. The seller as the organizer of the trading process must be able to predict which marketing activities will stimulate sales. One of the well-known and quite wide-spread methods of general sales promotion is the so-called "Black Friday" or the season of New Year sales. Like most marketing things, this method of boosting sales comes from the United States. Americans have been actively selling during this period for more than half a century. But in other countries, in particular in Ukraine, this marketing move started not so long ago, but has gained momentum. Marketing research shows that since 2013 consumers in Ukraine have been anticipating a grand event at the end of November, which they associate with huge discounts and sales. This event is called Black Friday in marketing. The event was first mentioned in 1961 in Philadelphia and for a long time the term had been used mostly on the East Coast of the United States, then throughout the country, and later around the world. The name "Black Friday" was invented as a metaphor for the terrible traffic and pedestrian jams that occurred after Thanksgiving.

From one-day Black Friday sales, American marketers have developed a marketing move called door-buster. It is a special offer for goods with a discount of up to $80-90 \%$ to the first visitors on this day. In recent years, Black Friday has become a global marathon of discounts, which begins on the fourth Friday in November and lasts November 23-29. At the moment Black Friday occupies a leading position in the US among the autumn-winter sales in terms of profitability in the segment of e-commerce, as well as the intensity of traffic and demand [11 p. 118]. In Ukraine, the seasonal sale, which corresponds to the traditions of Black Friday, usually begins on Thursday and lasts until the end of the calendar week, or even a 54 
month. Many stores hold the so-called presale (preparation for sale) from Monday in search of customer attention and benefits. According to the Google Trends service, customers' interest in sales on Black Friday is gradually increasing from Monday at the level of almost $8 \%$ and on Friday it takes a third (33.3\%) of all weekly Internet inquiries related to Black Friday both in Ukraine and in the world as a whole. It goes down on Friday and by Saturday the activity falls to the level of Tuesday [12]. Data on customers' interest in the Black Friday sale are shown in Fig. 1.

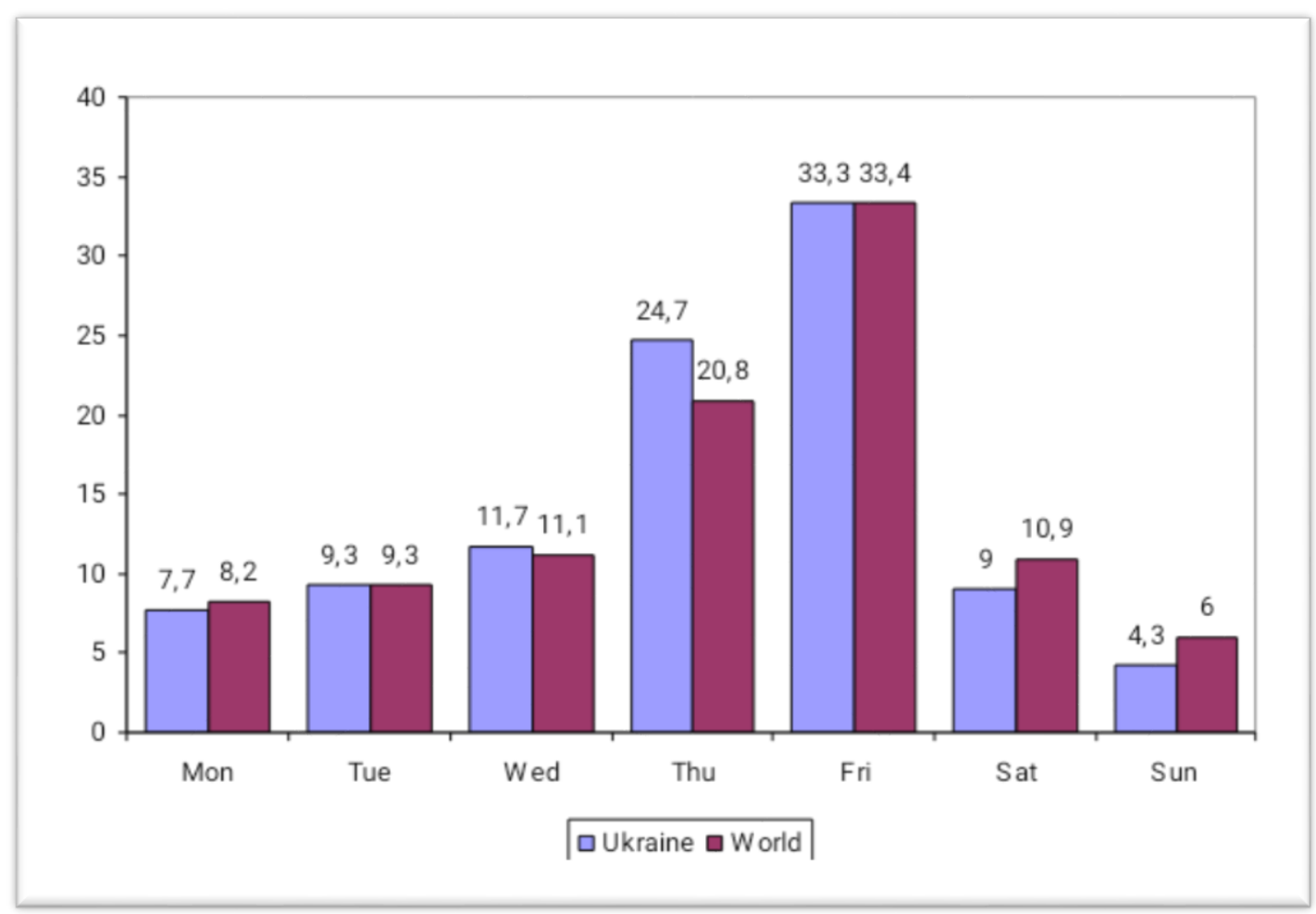

Figure 1 - Customers' interest in Black Friday sale during the week, $\%$. Source: compiled by the authors according to data [1].

Comparing the data of Ukrainian customers' interest in Black Friday sale with the generalized world indicator, the uniformity of inquiries on Friday $(33.3 \%$ and $33.4 \%$, respectively) has been noted. On Wednesday-Thursday, Ukrainian consumers' interest in retailing is higher by $+0.6 \%,+3.9 \%$, respectively), and on Saturday and Sunday it decreases $(-1.9 \%,-1.7 \%$ respectively) compared to the world indicators. By Saturday, activity falls to the level of Tuesday. The most active age audience is customers aged 35 to 44 . Their number is $630 \%$ larger than on a usual Friday, and the number of customers aged 55 to 64 on sale increases by $618 \%$ than usually [13].

The study of the geography of Black Friday sales in 2018 compared to the usual day shows the highest sales growth on this day in Germany - " $+2410 \%$ ", the UK - "+ 1708\%", and the lowest is in Thailand - only "+ 74\%" [1]. According to the data of the recent five years, the interest of Internet users in Black Friday has almost doubled, and the world average among 55 surveyed countries was $117 \%$. Both offline and online stores make profits that are sometimes higher than during half a year. In terms of countries, the largest increase in interest among potential customers is in South Africa - "+ 9900\%", Italy - "+ 3233\%", Japan - "+ 2400\%". Studies in Brazil show a decrease in consumer interest in sales - "-11\%". In recent years, the 
average growth of sales on Black Friday in Ukraine is growing by $419 \%$, compared with a usual day [12].

Discounts on this day range from 40 to $70 \%$. It is interesting that the expectations of Ukrainian consumers coincide with the discounts provided by stores. According to surveys in 2018 , consumers expected a discount of an average of $62 \%$, and the national average was recorded at $64 \%$. And this size of the discount was the highest among other countries. The average discount worldwide was recorded at $51 \%$ [1]. If we analyse the interest of Ukrainian consumers in Black Friday sales, it has doubled in the last five years: in 2015, 49\% of users were interested in this event, and in 2019,78\%, and this interest begins in early October each year. Analysis of Black Friday search during the last 30 days, as of 03.11.2020 is shown in Fig. 2.

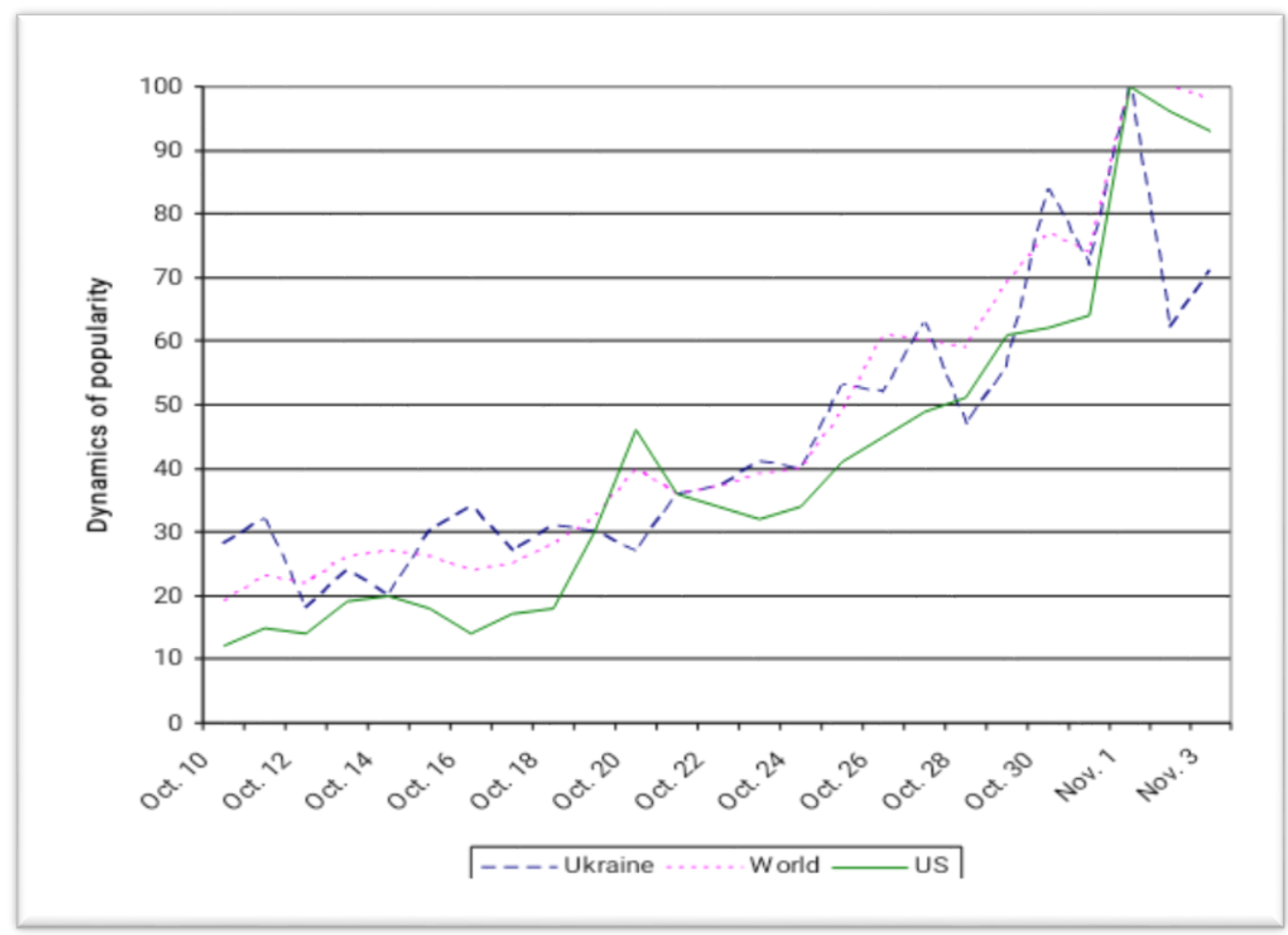

*The figures show the popularity of the search term relative to the highest point on the graph for a particular region and time period. 100 is the peak of the term popularity.

Figure 2 - Analysis of Black Friday search by customers from 11.10 to 03.11.2020. Source: compiled by the authors according to data [14].

Analysis of Black Friday search during the last 30 days using the Google Trends service, namely from 1 to 30 October 2020, indicates an increase in popularity. A month before the grand discounts, buyers are wondering when exactly to expect them. Sales are likely to decline now as customers try not to spend money until Black Friday to make the most profitable purchase.

The results of research by the online service Picodi.com in 2018 show that Ukrainians make online purchases mainly using a computer $-52 \%$, a smartphone $-42 \%$ and only $6 \%$ using a tablet. According to the study of Black-friday.global, in 2019 the statistics changed, and almost $54 \%$ of Ukrainian consumers made purchases using a smartphone, $41 \%$ - a computer and almost $5 \%$ - a tablet. The vast majority of Ukrainians pay by payment cards. According to PrivatBank, in 2018, 3.2 million purchases worth over UAH 1 billion were paid through the 
bank terminal system [15], and a record number of purchases in instalments under the "Payment in instalments" and "Instant instalments" programs - UAH 115 million, with more than half of this amount going to Ukrainian online stores. In 2019, on Black Friday only through the terminals of PrivatBank, buyers spent more than 1.3 billion hryvnias, and they made about 4.5 million purchases. As a result, the volume of purchases paid by cards broke the record of recent years, exceeding the daily average by 10 times and last year's results by $37 \%$. The purchase of goods in instalments also became a record - during the day the bank's customers bought goods for UAH 148 million with the help of the services "Payment in instalments" and "Instant instalments", which is $29.4 \%$ more than last year. At the same time, most of the bank's customers issued instalments in offline stores for a total of UAH 93.5 million, while online for UAH 55.3 million. On Black Friday, Alfa-Bank customers spent UAH 201 million on purchases, making 462,000 transactions. In total, over the weekend, the bank customers made 1.2 million purchases totalling UAH 481 million. [16]. In total, in 2019, Ukrainians spent \$ 7.5 billion on Black Friday shopping, which is USD 800 million more than the previous year. 40\% of purchases were made from smartphones. New fast websites and mobile applications make online shopping easy and fast, especially if you use Apple Pay or Google Pay. The most popular product categories are: headphones, game consoles, TVs and smartphones [17]. Global trends note that consumers are spending more and more money every year shopping on Black Friday. The analysis of consumer spending in the period of 2006-2019 during Black Friday seasonal sale is shown in Fig. 3.

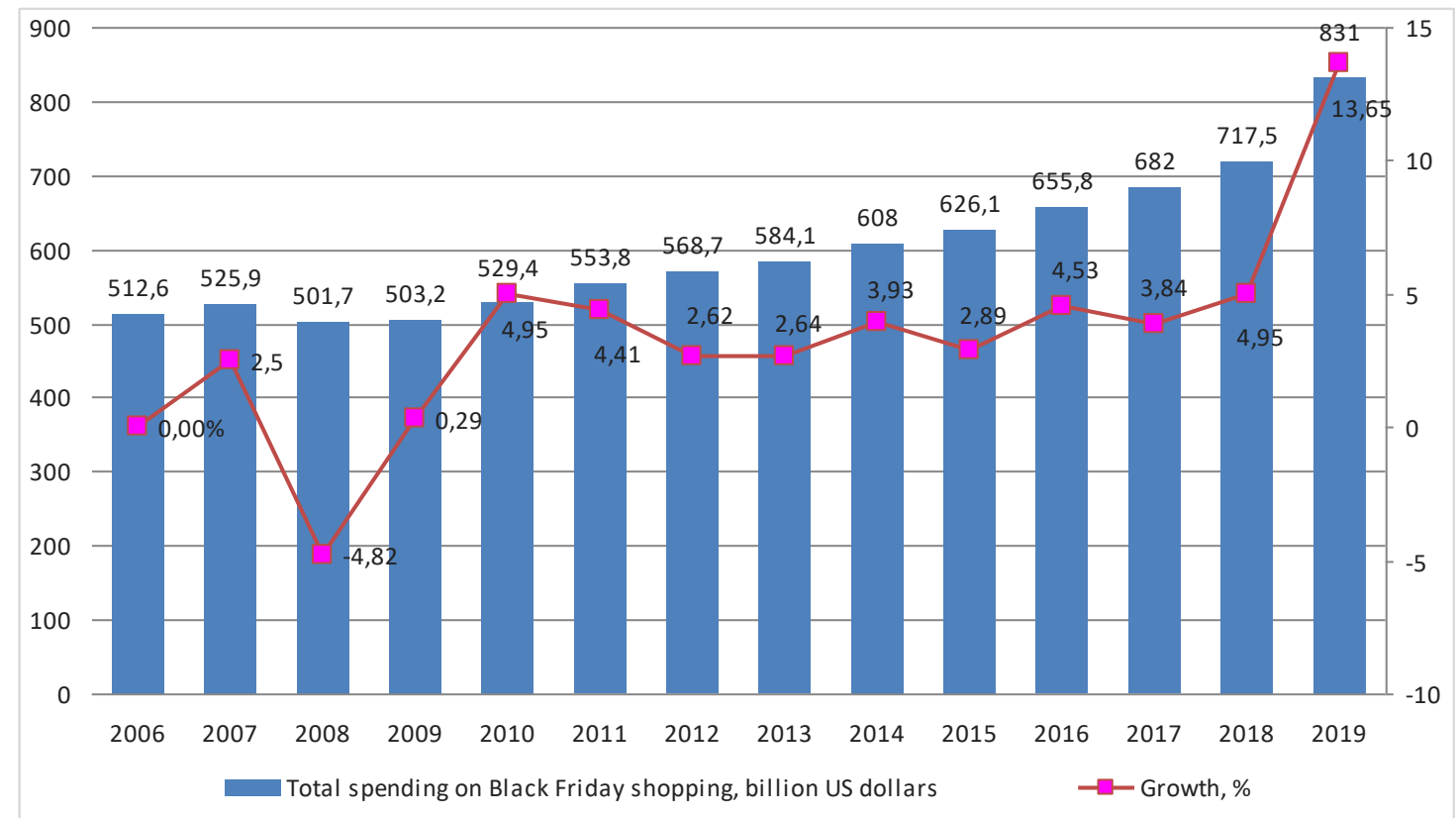

Figure 3 - Analysis of consumer spending during Black Friday in the world from 2006 to 2019, billion dollars USA.

Source: compiled by the authors according to data [20].

Between 2006 and 2019, Black Friday shopping spending increased by an average of $3.5 \%$. Black Friday spending fell by $4.82 \%$ only in the crisis year of 2008, but in 2010 the level of spending on purchases returned to the level of 2007, and then from year to year these figures increased. In 2019, consumers spent USD 831 billion on this day, which is USD 113.5 billion than in 2018 or $13.65 \%$, which is the highest figure over the last 15 years. 
Survey data on www.finder.com show that even if quarantine measures do not allow the use of "door-buster" sales, it will not stop the consumer from spending money on the biggest shopping holiday of the year. According to experts, spending in 2020 will increase by more than USD 148 billion. This year, the American consumer plans to spend money on furniture at a significant discount, while in recent years appliances and electronics were at the top of purchasing list.

Considering marketing communications to promote the product in $\mathrm{B} 2 \mathrm{C}$ market type, there is commitment of consumers to online sales. A clear example of the benefits of ecommerce among retail promotion channels is seen during the quarantine restrictions associated with COVID-19, as consumers began to rely on digital transactions amid the physical closure of stores and fear of infection. Data on e-commerce worldwide from 2014 and the forecast for 2023 (in billions of US dollars) are shown in Figure 4.

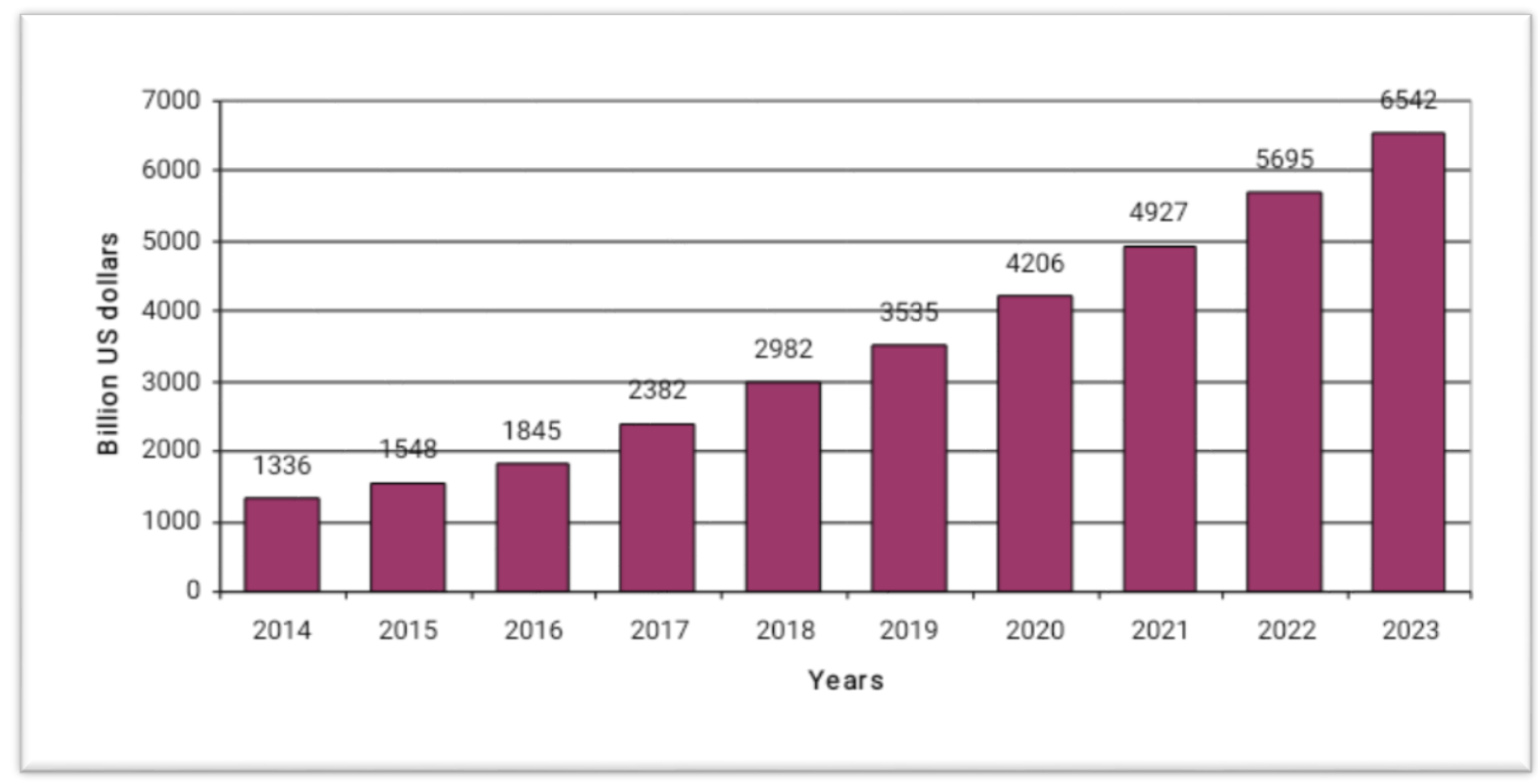

Figure 4 - Retail e-commerce in the world from 2014 to 202, billion dollars USA.

Source: compiled by the authors according to data [18].

In 2019, the volume of retail sales via the Internet amounted to USD 3.53 trillion worldwide. Revenue from e-retail is projected to grow to USD 6.54 trillion in 2023. Research shows that online shopping is one of the most popular types of e-business all over the world. Black Friday is a popular day for online shopping. In 2019, 93.2 million people shopped online on Black Friday, in 2018 this figure was much lower - 65.2 million, or $30 \%$ lower.

Electronic trading platforms and price aggregators, known as marketplaces are gaining special popularity. The differences between a trading platform and an online store seem obvious. If the online store presents the product of only one supplier, the electronic platform is a kind of catalogue of online stores, where the same product can be offered by different companies, so the buyer easily chooses the most profitable option for him [19]. The examples of such services on the world market are eBay, Amazon, Etsy and Alibaba Group (AliExpress, Taobao, etc.). In America and Europe, more than 200 marketplaces operate and effectively promote products. In Ukraine, such projects have been implemented by Rozetka, Prom.ua, Crafta, OLX, LaModa and other Internet companies. 
According to LetyShops service, in 2019 the share of orders from marketplaces was 93.62\%. Most orders are made on eBay, AliExpress, Rozetka. The most active customers were the residents of the capital. Kievans made $22.65 \%$ of purchases from the total number in the country. They are followed by the residents of Kharkiv $-6.5 \%$ and Odessa -5.15 of the total share of orders [20].

Promotion of goods through electronic trading platforms and price aggregators is a very effective marketing strategy, as they do not deal with the formation of orders, because it is the task of an individual seller, the task of marketplaces is to provide traffic, and its specialists conduct analytics and marketing support. In turn, retailers, focusing on consumer interest, have the opportunity to direct advertising efforts, such as targeted advertising, to the most interested customers.

Conclusions from this research and prospects for further developments in this area. So, B2C market analysis shows that the use of technology is changing the rules of doing business and approaches to sales promotion. Recently, there has been a trend of increasing purchases over the Internet. At the same time, traditional online stores are being replaced by electronic trading platforms and price aggregates (marketplaces), which provide customers with significant opportunities to meet consumer needs. Seasonal sales are the most popular among consumers, one of which is Black Friday. The number of consumer inquiries for sales and expected discounts is growing every year, and in this period sales of goods increase significantly in Ukraine and around the world. Further research is concerned with comparing Black Friday and Cyber Monday offerings, as well as identifying factors that affect sales during these periods.

1. Chornaya p'atnitsa 2020 [Black Friday 2020]. Available at: https://black-friday.global/ru-ua/ (accessed 05 October 2020).

2. Danyl'čenko A. (2018) Chorna pyatnyts'a: yak vdalo skupytys i ne rozorytys [Black Friday: how to do good purchases and not go bankrupt]. Available at: https://www.bbc.com/ukrainian/features46272648 (accessed 25 September 2020).

3. Biznes dl'a spozhyvach'a [Business for the consumer] (2018) Available at: https://uk.wikipedia.org/wiki/\%D0\%91\%D1\%96\%D0\%B7\%D0\%BD\%D0\%B5\%D1\%81_\%D0\%B4 \%D0\%BB\%D1\%8F_\%D1\%81\%D0\%BF\%D0\%BE\%D0\%B6\%D0\%B8\%D0\%B2\%D0\%B0\%D1\%87 $\%$ D0\%B0 (accessed 17 September 2020).

4. Chto takoye B2C [What is B2C]. (2020) Available at: https://temabiz.com/terminy/chto-takoeb2c.html (accessed 13 October 2020).

5. Dernova I. A. (2010) Val'utnyi kurs v konteksti zovnishniotorhovelnykh vidnosyn [Currency exchange rate in the context of foreign trade relations]. Prykladna statystyka: problemy teorii ta praktyky. Vol. 6, pp. 294-299.

6. Yatsiuk D. V. (2015) Tsyfrovyi marketynh: maibutn'e marketynhovykh komunikatsiy v brendynhu [Digital marketing: the future of marketing communications in branding]. Investments: practice and experience, no. 7 , pp. 70-74.

7. Philip Kotler (2007). Osnovy marketynha [Marketing essentials]. Available at: http://loveread.ec/read_book.php?id=66100\&p=140\#gl_289 (accessed 10 October 2020).

8. Karpenko Yu. M. (2016) Rozvytok zasobiv stymul'uvann'a zbutu v umovakh suchasnoho rynku [Development of sales promotion tools in the conditions of the modern market]. Scientific Bulletin of Polissya, no. 4 (8), p.2, pp.335-339.

9. Sheremetyns'ka O. V., Nevmerzhyts'ka Yu. (2016) Stymull'uvann'a zbutu: zakhody ta zasoby, yaki dopomahayut' pry formuvann'i marketynhovoi diyal'nosti pidpryiemstva pry zdiysnenni ZED [Sales promotion: measures and tools that help to form enterprise marketing activities when carrying out foreign economic activity]. Efektyvna ekonomika [Efficient economy] (electronic journal), vol. 2. Available at:: http://www.economy.nayka.com.ua/?op=1\&z=4785 (accessed 25 September 2020). 
10. Kal'nyts'ky A.Ye., Kopus'ak Ya. F. (2014) Stymull'uvann'a zbutu: zakhody ta zasoby, yaki dopomahayut' pry formuvann'i marketynhovoi diyal'nosti pidpryiemstva [Sales promotion: measures and tools that help to form enterprise marketing activities]. Scientific Bulletin of Uzhhorod University, vol. 1(42), pp. 94-97.

11. Kushnir D. S. (2020) Suchasni marketynhovi tekhnolohii analizu stymull'uvann'a zbutu [Modern marketing technologies of sales promotion analysis]. Proceedings of the Aktualni problem efektyvnoho sotsial'no-ekonomichnoho rozvytku Ukrainy: poshuk molodykh. (Ukrainian, Vinnyts'a, April 23, 2020), Vinnyts'a, Redaktsiyno-vydavnychyi viddil VTEI KNTEU, pp. 115-123.

12. Google Trends (2018) Available at: https://trends.google.com.ua/trends/explore?date $=2018-11$ $25 \% 202018-12-01 \&$ geo=UA\&gprop=news\&q=\%E2\%80\%9CBlack\%20Friday\%E2\%80\%9D (accessed 12 October 2020).

13. Chornaya p'atnitsa 2018 v Ukrain'e. Chto govoriat tsyfry [Black Friday 2018 in Ukraine. What do the figures say]. Available at: https://www.picodi.com/ua/mozhna-deshevshe/chyornaya-pyatnitsa2018-v-ukraine-chto-govoryat-tsifry (accessed 13 October 2020).

14. Google Trends (2020) Available at: https://trends.google.com/trends/explore?date=today\%201$\mathrm{m} \& \mathrm{geo}=\mathrm{UA} \& \mathrm{q}=\% 2 \mathrm{Fm} \% 2 \mathrm{~F} 0200 \mathrm{gn}$ (accessed 24 September 2020).

15. U "Chornu piatnyts'u ukraints'i vytratyly cherez treminaly Pryvatbanku bil'she mil'yarda [On Black Friday, Ukrainians spent more than a billion through Privatbank terminals]. Ekonomichna pravda (2018, November 27) Available at: https://www.epravda.com.ua/news/2018/11/27/643037/ (accessed 24 September 2020).

16. Горбань Yu. (2019) Yak proishla Chorna pyatnyts'a v Ukrain'I [How was Black Friday in Ukraine] Ukrinform. Available at: https://www.ukrinform.ua/rubric-society/2830748-ak-projsla-corna-patnicav-ukraini.html (accessed 24 September 2020).

17. Tokar N. (2019) 40\% pokupok u Chornu pyatnyts'u bulo zrobleno zi smartfoniv [40\% of Black Friday purchases were made from smartphones]. Tokar.ua. Available at: https://tokar.ua/read/38779 (accessed 23 September 2020).

18. Elektronna komertsia B2C. Svitovi rozdribni prodazhi eletronnoi komertsii 2014-2023 [World retail e-commerce sales from 2014 to 2023]. Available at: https://www.statista.com/statistics/379046/ worldwide-retail-e-commerce-sales/\#statisticContainer (accessed 20 October 2020).

19. Marketplace: Osoblyvosti ta vidminnosti vid internet-mahazynu (2020) [Marketplace: features and differences from the online store]. Available at: https://marketer.ua/ua/marketplace-features-anddifferences-from-the-online-store/ (accessed 24 September 2020).

20. What Is Black Friday? (2020) Available at: https://www.thebalance.com/what-is-black-friday3305710 (accessed 24 September 2020).

21. William Eve (2020) Rozprodazhi chornoi pyatnyts'I ta kiberponedilka [Black Friday and Cyber Monday sales]. Available at: www.finder.com (accessed 23 September 2020).

I.B. Іванова, кандидат педагогічних наук, доиент, доцент кафедри економіки, підприємництва та маркетингу, Черкаський державний бізнес-коледж (Черкаси, Украӥна)

T.М. Боровик, старший викладач кафедри економіки, підприємництва та маркетингу, Черкаський державний бізнес-коледж (Черкаси, Україна)

А.Ю. Руденко, викладач кафедри економіки, підприємництва та маркетингу, Черкаський державний бізнес-коледж (Черкаси, Україна)

Т.Г. Залозна, викладач кафедри економіки, підприємництва та маркетингу, Черкаський державний бізнес-коледж (Черкаси, Україна)

\section{Чорна п'ятниця як інструмент стимулювання збуту}

У статті розкрито особливості просування та стимулювання продажу на ринках типу B2C (Business-to-Consumer). Обтрунтовано використання інструментів ијифрового маркетингу y процесі стимулювання продажу товару за допомогою цифрових каналів, зокрема через інтернет-магазини, а також застосування пошукового просування (SEO) та SMM-маркетингу. Розглянуто маркетингові комунікаиії та елементи стимулювання продажу, що застосовуються рітейлерськими компаніями при підготовиі до сезонних розпродажів. 
Досліджено активність споживачів до рітейлерів у період підготовки до розпродажів, інструменти, що використовує роздрібна торгівля з метою впливу на споживача та підвищення активності продажу товарів. Узагальнено та проаналізовано статистичні дані онлайнплатформ Black-friday.global, Picodi, Google Trends. Досліджено чинники, щзо впливають на можливості інтернет-магазинів та роздрібної торгівлі під час "Чорної п'ятниці». Висвітлено особливості функиіонування торгових платформ, які надають торгові онлайн-площі та забезпечують маркетингові комунікаиї̈ у мережі Інтернет.

Ключові слова: просування товару, стимулювання збуту, Чорна п’ятниця, маркетингові комунікації, цифровий маркетинг, рітейл, маркетплейс.

Received to the editor 17 June 2020. 